\title{
Identifikasi Vertebrata Kelas Mamalia di Taman Satwa Taru Jurug Surakarta Sebagai Bahan Materi Pengembangan Video Pembelajaran Biologi SMA Kelas X
}

\author{
Ibnu Fadhlianto \\ SMA Veteran 1 Sukoharjo \\ Jalan dr. Muwardi No.84, Sawah, Gayam, Sukoharjo, Jawa Tengah \\ E-mail: ibnufadhlijanuar@gmail.com \\ diterima: 15 Agustus 2020 disetujui: 22 Agustus 2020, dipublikasikan: 30 September 2020
}

\begin{abstract}
The purpose of this study was to identify Vertebrate animals of the Mammal class, order artiodactyla, family Cervidae in the Jurug Surakarta Taru Animal Park, develop interactive video media as a result of identification of vetebrata animals into learning media, know the quality of interactive video media based on assessment by material experts, media experts and biology teachers, and applications in learning. The research method used an observation method by making direct observations of vertebrate species. The instrument for assessing the quality of interactive video media is based on material aspects and presentation aspects, with a qualitative descriptive analysis design. The results of this study indicated that in Taru Jurug Animal Park Surakarta there were 3 species of animals namely Cervus unicolor, Cervus timorensis, Axis-axis and all three have been identified. Research on the identification of vertebrate animals, especially the mammalian class, order artiodactyla, and the cervidae family can be used for the preparation of interactive video media with material on Biodiversity at the level of genes and species. The quality of interactive video media in terms of material aspects, presentation, and language. Assessment of material experts obtained a percentage of $90.9 \%$ so that it was categorized as very valid, media experts obtained a percentage of $88.5 \%$ so it was categorized as very valid, biology teacher Veteran 1 Sukoharjo High School obtained a percentage of $92.5 \%$ so it was categorized as very valid and biology teacher Nguter 1 Public High School obtained a percentage of $97.5 \%$ so it is categorized as very valid. Based on this, it can be concluded that this interactive video media is worthy of being used by teachers as one of the learning media about Biodiversity at the level of genes and species.
\end{abstract}

Keywords: identification, interactive video quality and media, Cervus unicolor, Cervus timorensis, Axis-axis

\section{PENDAHULUAN}

Pengetahuan adalah reaksi dari manusia atas rangsangannya oleh alam sekitar melalui persentuhan objek dengan indera dan pengetahuan merupakan hasil yang terjadi setelah orang melakukan penginderaan sebuah objek tertentu (Pudjawidjana, 1983).

Sains (biologi, fisika, kimia) memiliki kontribusi yang cukup besar dalam perkembangan teknologi, yakni sebagai ilmu dasar yang melandasi pengembangan teknologi. Hal ini yang menyatukan keduanya menjadi kesatuan yang dikenal sebagai Saintek/IPTEK (Sudarisman, 2015).
SMA N 1 Nguter adalah salah satu sekolah di Kabupaten Sukoharjo, sedangkan SMA Veteran 1 Sukoharjo merupakan salah satu sekolah swasta yang juga terletak di Kabupaten Sukoharjo. Namun dalam pembelajaran keanekaragaman hayati, masih ada siswa yang masih remedial di kedua SMA tersebut. Di SMA N 1 Nguter, KKM untuk pelajaran keanekaragaman hayati adalah 70. Sedangkan prosentase nilai murid kelas 10 yang tuntas kurang dari 50\%. Pembelajaran biologi kelas 10 sendiri lebih banyak menggunakan powerpoint berupa slide tulisan saja karena mengacu pada kurikulum 2013, akan tetapi penggunaan 
media untuk pelajaran keanekaragaman hayati sendiri belum ada. Di SMA Veteran 1 Sukoharjo, KKM untuk pelajaran Keanekaragaman Hayati adalah 68. Sedangkan prosentase nilai murid kelas 10 yang tuntas kurang dari 50\%. Pembelajaran biologi kelas 10 sendiri lebih banyak menggunakan powerpoint berupa slide tulisan dengan gambar saja karena mengacu pada kurikulum 2013, akan tetapi penggunaan media untuk pelajaran keanekaragaman hayati sendiri belum ada

Pembelajaran materi keanekaragaman hayati memerlukan bantuan media pembelajaran agar siswa dapat lebih memahami materi karena pengetahuan yang berasal dari buku pegangan siswa terkadang kurang dapat memberikan gambaran yang lengkap dan jelas terhadap apa yang ada di alam terutama lingkungan sekitar.

Pada penelitian ini, tempat yang digunakan untuk identifikasi adalah Taman Satwa Taru Jurug, letaknya di timur kota Surakata, dekat perbatasan dengan Karanganyar. Di dalam Taman Satwa Taru Jurug terdapat berbagai spesies hewan seperti gajah, ular, harimau sumatra, rusa, unta, beruang madu, siamang, dan masih banyak fauna lainnya. Hasil penelitian ini di harapkan dapat digunakan sebagai salah satu sumber pembelajaran biologi di SMA kelas $X$ pada BAB II Berbagai Tingkat Keanekaragaman Hayati. Metode pembelajaran seperti ini juga pernah dilaporkan Dhesti (2020) mengenai materi Aves untuk jenjang SMA.

\section{METODE}

Lokasi penelitian dilakukan di Taman Satwa Taru Jurug Surakarta dan waktu penelitian di mulai pada bulan Januari 2019
Alat dan Bahan yang digunakan adalah Kamera, Alat tulis, Lembar Pengamatan, Hewan Tingkat Gen dan Tingkat Spesies, Buku Materi Vertebrata, Internet

\section{Metode Penelitian}

Penelitian ini dilakukan dengan menggunakan metode eksplorasi dan pembuatan media. Sehingga penelitian hanya menggunakan bantuan alat tulis, kamera serta narasumber yang berada di Taman Satwa Taru Jurug Surakarta.

Pengumpulan data dilakukan dengan teknik observasi, pengamatan dan dokumentasi. Peneliti berperan sebagai instrumen kunci pada penelitian ini.

\section{Prosedur Penelitian}

Dalam penelitian ini menggunakan langkah langkah penyusunan media adalah sebagai berikut:

1. Pengumpulan data dan analisis

a) Melakukan pengamatan dan identifikasi terhadap hewan vertebrata khususnya kelas mamalia, ordo artiodactyla, dan famili cervidae yang ada di Taman Satwa Taru Jurug Surakarta.

b) Mengumpulkan data hasil identifikasi dan mengumpulkan sumber. Sumber yang dimaksud seperti buku teks, buku referensi, materi-materi sumber asli, internet, maupun pengetahuan dari orang lain dibidang tersebut yang mendukung pembuatan bahan ajar.

2. Rancangan

a) Merancang desain produk untuk mempermudah dalam penyusunan media pembelajaran.

\section{Pembuatan}

a) Membuat media pembelajaran dari hasil pengumpulan dan analisis data yang dijadikan sebuah video pembelajaran dan dipadukan dengan powerpoint.

b) Variasi desain produk, dalam tahap ini dilakukan penilaian dengan cara 
menghadirkan pakar atau tenaga ahli untuk menilai produk yang dirancang.

c) Perbaikan desain, setelah desain produk divalidasikan melalui penilaian para ahli, maka akan diketahui kelemahannya. Kelemahan tersebut selanjutnya diminimalisir dengan cara memperbaiki desain.

\section{Penggunaan}

a) Media pembelajaran berupa video interaktif digunakan oleh guru biologi di SMA N 1 Wuryantoro dan SMA Veteran 1 Sukoharjo.

\section{Teknik Analisis Data}

1. Analisis Spesies Vertebrata

Data yang telah dikumpulkan dalam penelitian mengenai spesies-spesies vertebrata kelas mamalia, ordo artiodactyla, dan famili cervidae kemudian di identifikasi dengan bantuan buku vertebrata dan internet. Data yang telah jadi kemudian dibuat media pembelajaran interaktif dengan bantuan internet.

\section{Uji Validasi Media}

Hasil penelitian yang disusun dalam bentuk media selanjutnya dilakukan validasi oleh ahli materi, ahli media, dan guru biologi sebagai pengguna untuk mengetahui apakah media yang disusun layak untuk dijadikan media pembelajaran atau tidak. Validator ahli materi adalah dosen Universitas Veteran
Bangun Nusantara Sukoharjo, dengan ketentuan memiliki kualifikasi akademik minimal Magister (S2) dan berpengalaman. Sedangkan validator ahli media adalah dosen atau ahli dengan ketentuan memiliki kualifikasi dibidang media pembelajaran. Selanjutnya dilakukan uji coba media pembelajaran pada pengguna yaitu Guru Biologi tingkat SMA. Data yang dipakai dalam validasi media ini merupakan data kuantitatif dengan menggunakan lima tingkatan yang memiliki kriteria seperti pada tabel berikut.

Tabel 1 Penskoran validasi media

\begin{tabular}{lll}
\hline No. & Skor & Keterangan \\
\hline 1. & 5 & Penilaian media sangat baik \\
2. & 4 & Penilaian media baik \\
3. & 3 & Penilaian media cukup baik \\
4. & 2 & Penilaian media kurang baik \\
5. & 1 & Penilaian media tidak baik \\
\hline
\end{tabular}

Data hasil validasi selanjutnya dianalisis menggunakan teknik analisis data presentase dengan rumus berikut :

$$
p=\frac{\sum^{n} x}{\sum^{n} y} 100 \%
$$

Data presentase penilaian yang telah diperoleh diubah menjadi data kualitatif deskriptif yang menggunakan kriteria validitas pada tabel berikut:

Tabel 2. Kriteria Validitas

\begin{tabular}{|c|c|c|c|}
\hline No & Tingkat Validasi & Kategori Kevalidan & Keputusan \\
\hline 1. & $80 \%-100 \%$ & Sangat Valid & $\begin{array}{c}\text { Media siap dimanfaatkan sebagai sumber } \\
\text { belajar di SMA/MA }\end{array}$ \\
\hline 2. & $60 \%-79 \%$ & Valid & $\begin{array}{l}\text { Media dapat dilanjutkan dengan menambah } \\
\text { sesuatu yang kurang melakukan } \\
\text { pertimbangan-pertimbangan tertentu. } \\
\text { Penambahan yang dilakukan tidak terlalu } \\
\text { besar dan tidak terlalu mendasar. }\end{array}$ \\
\hline
\end{tabular}

3. $50 \%-59 \% \quad$ Kurang Valid 


\section{A. Hasil Penelitian}

\section{Deskripsi Lokasi dan Waktu Studi}

Taman Satwa Taru Jurug berada di tepian sungai Bengawan Solo, sekitar $10 \mathrm{~km}$ dari Pusat Kota Surakarta, berada di ketinggian sekitar 92m diatas permukaan air laut. Dengan luas sekitar 13,9 ha, terletak 110 45' 15" - 110 45' 35" Bujur Timur dan 70' 36" - 70' 56" Lintang selatan. Taman Satwa Taru Jurug Surakarta ( TSTJ ) adalah sebuah taman yang ditopang oleh 67 jenis satwa dan 331 ekor satwa serta ditumbuhi lebih dari ribuan pohon yang membuat suasana lingkungan menjadi sejuk dan nyaman.

Taman Satwa Taru Jurug Surakarta ( TSTJ ) pada awalnya merupakan pindahan Kebun Binatang Sriwedari yang lebih dikenal dengan sebutan "Kebun Rojo", didirikan Sri Susuhunan Paku Buwono X pada tanggal 20 Dal 1381 atau tanggal 17 Juli 1901 dan merupakan Kebun Binatang tertua.

Identifikasi hewan vertebrata khususnya kelas mamalia, ordo artiodactyla, dan famili cervidae di Taman Satwa Taru Jurug Surakarta dilaksanakan selama 7 hari yaitu pada tanggal 17 - 22 Januari 2019. Identifikasi hewan vertebrata dilakukan dengan cara melihat morfologi (sifat yang nampak dari luar) dari tubuh hewan vertebrata tersebut. Setelah di identifikasi, data tersebut dapat digunakan sebagai bahan pembuatan media pembelajaran berupa Video Interaktif untuk pembelajaran SMA dan MA dengan K.D 3.2 Menganalisis data hasil observasi tentang berbagai tingkat keanekaragaman hayati (gen, jenis dan ekosistem) di Indonesia.

\section{Hasil Identifikasi}

Kegiatan awal sebelum melakukan pengembangan media pembelajaran video interaktif adalah melakukan pengamatan dan identifikasi hewan vertebrata khususnya kelas mamalia, ordo artiodactyla, dan famili cervidae di Taman Satwa Taru Jurug Surakarta.

Adapun identifikasi hewan tersebut sebagai berikut :

a. Individu Rusa 1

Deskripsi
Rusa ini mempunyai ciri-ciri tubuh berwarna gelap dengan warna rambut coklat tua, mempunyai tubuh yang tinggi, mempunyai kaki yang panjang, bagian pada perut terlihat lebih gelap. Hal ini sesuai dengan teori Anderson (1967) bahwa rusa ini termasuk rusa Asia dengan ciri-ciri tubuh yaitu tinggi pundak mencapai $102-160 \mathrm{~cm}$ dengan bobot badan mencapai $546 \mathrm{~kg}$. Panjang badan pada rusa jantan dapat mencapai $160 \mathrm{~cm}$ dengan berat badan antara 136-320 kg, sedangkan rusa yang betina mencapai $115 \mathrm{~cm}$ dengan berat badan 135$225 \mathrm{~kg}$. Rusa ini juga merupakan jenis rusa yang besar dan mempunyai kaki yang panjang, warna kulit dan rambut coklat tua, bagian perut berwarna lebih gelap sampai kehitam-hitaman, rambut kuku kasar dan pendek. Nama latin rusa ini Cervus unicolor.

b. Individu Rusa 2

\section{Deskripsi}

Rusa ini mempunyai ciri-ciri tubuh berwarna gelap dengan warna rambut coklat tua bercampur dengan sedikit warna abu-abu, memiliki ukuran tubuh sedikit lebih kecil dibanding Cervus unicolor, pada rusa jantan memiliki ranggah atau tanduk yang bercabang tiga dan jika sudah dewasa terdapat tiga ujung yang runcing. Hal ini sesuai dengan teori Alam Endah (2010) bahwa rusa ini jika dewasa mempunyai panjang badan berkisar antara 195-210 cm dengan tinggi badan mencapai antara 91-110 $\mathrm{cm}$. Mempunyai berat badan antara 103-115 $\mathrm{kg}$, walaupun rusa yang berada dipenangkaran mampu memiliki bobot sekitar $140 \mathrm{~kg}$. Ukuran rusa ini meskipun kalah besar Cervus unicolor namun dibandingkan dengan rusa jenis lainnya seperti rusa bawean dan menjangan, ukuran tubuh rusa timor lebih besar. Rusa jantan memiliki tanduk (ranggah) yang bercabang. Tanduk akan tumbuh pertama kali pada anak jantan saat umur 8 bulan. Setelah dewasa, 
tanduk menjadi sempurna yang ditandai dengan terdapatnya 3 ujung runcing. Habitat rusa ini adalah padang rumput pada daerah beriklim tropis dan subtropis, dan menjadi fauna identitas Nusa Tenggara Barat. Nama latin rusa ini Cervus timorensis.

\section{c. Individu Rusa 3}

Deskripsi

Rusa ini mempunyai ciri-ciri tubuh berwarna terang dengan warna rambut coklat muda dengan corak totol putih di tubuhnya, terdapat garis dengan warna gelap di sepanjang punggung sampai pangkal ekor, memiliki leher yang pendek, kelopak mata besar, mempunyai tanduk (ranggah) yang hanya tumbuh pada rusa jantan, memiliki ukuran tubuh yang kecil, bagian bawah rusa berwarna putih, dan memiliki ekor yang agak panjang. Hal ini sesuai dengan teori Grzimek (1972) bahwa rusa ini memiliki leher kepala yang pendek, memiliki senjata di atas kepalanya, mata yang terbilang besar, kelopak mata di sebelah atas memiliki rambut mata yang lebih panjang dari rambut mata sebelah bawah, kaki yang panjang, tubuh yang panjang dan mempunyai sebuah ekor yang panjang. Daerah telinga, ekor dan leher berambut lebih panjang dari bagian lainnya. Pada daerah punggung terdapat garis gelap yang membujur dari kepala sampai dengan pangkal ekor. Pada dada terdapat bintik-bintik yang menyerupai garis putih, biasanya satu atau dua deretan bintik bintik. Bagian bawah rusa ini berwarna putih. Dan menurut Santra (2008), rusa ini mempunyai berat hampir mencapai $85 \mathrm{~kg}$. Yang medium dapat berdiri tegak hingga 35-38 inchi di bagian punggung. Ukuran lingkar dada 75-79 $\mathrm{cm}$, panjang ekor 20-10 cm, tinggi bahu 110$140 \mathrm{~cm}$ dan berat dewasa $75-100 \mathrm{~kg}$.

Jadi dari uraian hasil identifikasi di atas adalah hewan vertebrata yang teridentifikasi ada 3 spesies, dan ketiganya masuk ke dalam kelas mamalia, ordo artiodactyla, dan famili cervidae. Berikut adalah tabel daftar hewan vertebrata kelas mamalia, ordo artiodactyla, dan famili cervidae.

Tabel 3. Nama Jenis Rusa

\begin{tabular}{lll}
\hline No. & Nama Latin & Nama Lokal \\
\hline 1. & Cervus unicolor & Rusa Sambar \\
2. & Cervus timorensis & Rusa Timor \\
3. & Axis-axis & Rusa Tutul \\
\hline
\end{tabular}

\section{Hasil Identifikasi sebagai Bahan Pembuatan Media}

Hasil identifikasi rusa di Taman Satwa Taru Jurug Surakarta dapat digunakan sebagai bahan pembuatan media pembelajaran video interaktif pada materi Keanekaragaman Hayati tingkat gen dan spesies pada KD 3.2 yaitu "Menganalisis data hasil observasi tentang berbagai tingkat keanekaragaman hayati (gen, jenis, dan ekosistem) di Indonesia”, dengan menggunakan hasil identifikasi sebagai contoh keanekaragaman hayati tingkat gen dan tingkat spesies yaitu Cervus unicolor, Cervus timorensis, dan Axis-axis.

\section{Hasil Validasi Media}

Media pembelajaran video interaktif yang dibuat dari hasil identifikasi di Taman Satwa Taru Jurug Surakarta di uji validasinya kepada ahli materi, ahli media, dan pengguna yaitu guru biologi. Didapatkan hasil validasi oleh ahli materi dengan jumlah skor 40 dan perolehan prosentase sebesar 90,9\%; sedangkan hasil validasi oleh ahli media dengan jumlah skor 85 dan perolehan prosentase sebesar $88,54 \%$; begitu juga hasil validasi oleh pengguna yaitu guru biologi, dalam hal ini peneliti menguji kepada dua guru biologi dengan hasil validasi guru $\mathrm{A}$ jumlah skor 74 perolehan prosentase sebesar 92,5\% dan guru B jumlah skor 78 perolehan 
prosentase sebesar 97,5\%. Dari perolehan prosentase keempat validator tersebut bisa dikatakan bahwa media pembelajaran video interaktif masuk kriteria Sangat valid.

\section{Alternatif dalam Pembelajaran}

Media yang sudah divalidasi dan diperoleh hasil yang Sangat Valid dapat digunakan oleh guru sebagai solusi dari permasalahan tidak adanya media berupa video interaktif yang digunakan dalam pembelajaran biologi di Sekolah.

\section{B. Pembahasan}

\section{Pembahasan Hasil Identifikasi Hewan Vertebrata}

Dalam identifikasi di Taman Satwa Taru Jurug Surakarta peneliti mendapatkan 3 kelompok spesies vertebrata dengan kelas, ordo, dan famili yang sama yaitu kelas mamalia, ordo artiodactyla, dan famili cervidae.

Peneliti mendapatkan 3 jenis hewan vetebrata yang terdiri dari Rusa Sambar (Cervus unicolor), Rusa Timor (Cervus timorensis), dan Rusa Tutul (Axis-axis). Ketiga hewan tersebut sama-sama masuk kedalam kelas Mamalia karena tubuhnya ditutupi rambut, bernapas dengan paru-paru, dan pembiakan pada mamalia terjadi secara vivipar dan fertilisasi internal. Dan samasama masuk kedalam ordo Artiodactyla yaitu mamalia yang mempunyai jari kaki genap (Mendy Aisha, 2018).

Kemudian ketiga hewan tesebut dikelompokkan berdasarkan tingkat keanekaragaman hayati yaitu tingkat spesies (jenis) dan tingkat gen.

a. Keanekaragaman Hayati Tingkat Spesies

Keanekaragaman hayati tingkat spesies yaitu segala perbedaan (fisik, tingkah laku, dan habitat) yang ditemui pada makhluk hidup antar jenis atau antar spesies disebut dengan keanekaragaman hayati tingkat jenis atau spesies. Spesies merupakan sekelompok makhluk hidup yang mempunyai sifat-sifat yang sama dapat mengadakan perkawinan antarsesamanya dan menghasilkan keturunan yang fertil.

Rusa Sambar (Cervus unicolor), Rusa Timor (Cervus timorensis), dan Rusa Tutul (Axis-axis) termasuk kedalam keanekaragaman hayati tingkat spesies, karena ketiga hewan tersebut masuk kedalam ordo dan famili yang sama yaitu ordo Artiodactyla dan famili Cervidae tetapi mempunyai perbedaan bentuk fisik, tingkah laku, dan habitat (Muhammad Fadhli Masykuri, 2013).

b. Keanekaragaman Hayati Tingkat Gen

Keanekaragaman hayati pada tingkatan ini menyebabkan variasi antar individu dalam satu spesies. Ini terjadi akibat adanya variasi gen yang berbeda pada setiap individu sejenis. Gen sendiri adalah materi dalam kromosom makhluk hidup yang mengendalikan sifat organisme. Gen ini menyebabkan adanya suatu variasi yang nampak (fenotipe) dan variasi yang tidak nampak (genotipe). Susunan gen ini pada setiap makhluk hidup akan berbeda karena gen merupakan hasil dari campuran gen betina dan gen jantan ketika dalam proses perkawinan.

Dalam hal ini, peneliti mengambil sampel pada Rusa Tutul (Axis-axis). Dari hasil observasi di Taman Satwa Taru Jurug Surakarta ditemukan dua individu dalam satu spesies Rusa Tutul terdapat perbedaan pada ranggah atau tanduk, satu individu rusa memiliki sepasang tanduk yang sama panjang serta cabang tanduk yang sama dan satu individu rusa lainnya memiliki sepasang tanduk yang tidak sama panjang dan bentuk cabang yang berbeda. Peristiwa itu dapat dikatakan bahwa dua individu rusa tersebut masuk kedalam keanekaragaman tingkat gen 
karena adanya suatu variasi yang nampak (fenotipe) dalam satu spesies. Hal tersebut didukung pernyataan Primadya Anantyarta (2017) dalam jurnal penelitiannya mengatakan Sampel kerbau yang digunakan dalam penelitian ini berjumlah 8 ekor kerbau Jawa Timur. Penentuan sampel kerbau dilakukan dengan teknik random sampling. Pengambilan sampel darah dilakukan oleh dokter hewan, sedangkan pengamatan fenotip dilakukan oleh sejawat peneliti dengan data fenotip yang dimiliki. diketahui bahwa panjang tanduk kerbau berkisar antara $12 \mathrm{~cm}$ hingga $21 \mathrm{~cm}$. Lingkar dada yang dimiliki kerbau berkisar antara $146 \mathrm{~cm}$ hingga 190 $\mathrm{cm}$, tinggi badan yang dimiliki kerbau berkisar antara $112 \mathrm{~cm}$ hingga $125 \mathrm{~cm}$, ukuran kepala sampel kerbau berkisar $31 \mathrm{~cm}$ hingga $59 \mathrm{~cm}$, panjang leher kerbau berkisar $34 \mathrm{~cm}$ hingga $43 \mathrm{~cm}$, sedangkan panjang ekor sampel kerbau berkisar antara $68 \mathrm{~cm}$ hingga $82 \mathrm{~cm}$.

Dalam jurnal penelitian tersebut didapatkan hasil pengamatan fenotip pada kerbau Jawa Timur dari masing-masing individu berbeda, mulai dari panjang tanduk, lingkar dada, tinggi badan, ukuran kepala, panjang leher, dan panjang ekor. Ini semua dipengaruhi oleh gen yang dikandung masing-masing individu kerbau berbeda, begitu juga dengan pengamatan pada tanduk rusa tutul di Taman Satwa Taru Jurug Surakarta yang berbeda bentuk dan panjang, hal tersebut juga dipastikan dipengaruhi oleh kandungan gen didalam tubuh rusa tutul juga bebeda.

2. Media Pembelajaran Video Interaktif Hasil penelitian ini disusun dalam bentuk Media Pembelajaran Video Interaktif. Media tersebut tersebut bernama "SMART Biodiversity" memiliki arti kata "Smart" dalam bahasa Inggris adalah Pintar, kata "Biodiversity" yang berarti Biodiversitas
(Keanekaragaman Hayati) adalah materi yang dibahas dalam media tersebut. Dengan adanya media pembelajaran tersebut, diharapkan siswa dapat lebih memahami materi pembelajaran yang disampaikan. Sebagaimana dijelaskan oleh Dewy (2016) bahwa bahwa media pembelajaran adalah komponen integral dari sistem pembelajaran. Dalam kegiatan pembelajaran, seorang guru sebaiknya menggunakan alat bantu ajar berupa modul, jobsheet, model, atau alat bantu ajar lainnya yang dapat membantu siswa memahami pelajaran dengan mudah serta memberikan pengalaman yang konkrit.

\section{a. Pembuatan Multimedia Interaktif}

Pembuatan multimedia interaktif ini melewati beberapa tahap yang dikerjakan sesuai prosedur yaitu tahap perencanaan, tahap design, dan tahap pengembangan.

1) Planning (perencanaan )

a) Melakukan pengamatan dan identifikasi

Kegiatan awal sebelum melakukan pembuatan multimedia interaktif adalah melakukan pengamatan dan identifikasi hewan vertebrata khususnya kelas mamalia, ordo artiodactyla, dan famili cervidae di Taman Satwa Taru Jurug Surakarta. Hasil dari identifikasi tersebut diperoleh data, bahwa di Taman Satwa Taru Jurug Surakarta terdapat hewan kelas mamalia, ordo artiodactyla, dan famili cervidae yang berjumlah 3 Spesies.

b) Mengumpulkan sumber

Setelah melakukan identifikasi insecta dan memperoleh data yang cukup, maka tahap selanjutnya adalah mengumpulkan sumber refrensi yang menunjang pengembangan multimedia interaktif. Sumber referensi diperoleh dari sumber yang relevan yaitu : 
(a) Jurnal berjudul Jenis Dan Prevalensi Endoparasit Pada Feses Rusa Sambar (Cervus Unicolor) Dan Rusa Tutul (AxisAxis) Di Penangkaran Rusa Universitas Sumatera Utara oleh Henni Lasria Sibarani (2018).

(b) Web berjudul Rusa Timor Fauna Identitas Provinsi NTB oleh Alam Endah (2010).

(c) Buku "Modul Pengayaan Biologi Peminatan untuk SMA/MA Kelas X" oleh Muhammad Fadhli Masykuri (2013).

(d) Buku "Silabus SMA/MA Kelas X Kurikulum 2013" SMA Veteran 1 Sukoharjo. (e) Buku "RPP SMA/MA Kelas X Kurikulum 2013" SMA Veteran 1 Sukoharjo. Sumber informasi yang mendukung dari perencanaan diatas dikumpulkan dari berbagi sumber. Sumber informasi tersebut kemudian digunakan sebagai referensi dalam pengembangan multimedia interaktif. Sumber referensi dikumpulkan dari internet, buku ataupun jurnal yang mendukung pengembangan bahan ajar tersebut.

c) Menghasilkan gagasan

Setelah sumber yang diperoleh lengkap kemudian penelitian berkonsultasi dengan dosen pembimbing dan bertukar pendapat dengan teman sejawat, sehingga menghasilkan gagasan untuk selanjutnya dikembangkan menjadi media pembelajaran video interaktif.

Setelah mendapatkan data, selanjutnya disusun draf yang membantu memudahkan dalam pengembangan media pembelajaran video interaktif. Sehingga membentuk suatu gagasan yang kemudian dapat dikembangkan.

2) Design (tujuan)

Pembuatan design meliputi, diantaranya :

a) Membuat desain dan draf media video interaktif
Desain multimedia interaktif dan draf multimedia interaktif yang dibuat desesuaikan dengan langkah-langkah penyusunan sebuah media video interaktif, sehingga dapat mempermudah proses pengembangan.

b) Pengisian Format Media Video Interaktif

Pengisian format media video interaktif dilakukan sesuai dengan sistematika penulisan media pembelajaran video interaktif.

3) Development (pengembangan)

Pengembangan meliputi memproduksi multimedia interaktif, mengevaluasi dan meninjau kembali produk.

a) Memproduksi Multimedia Interaktif

Sebelum ketahap ini desain dan draf media pembelajaran video interaktif harus sudah selesai. Kemudian tahap produksi dapat dilakukan. Kendala pada tahap ini adalah ketika adanya kesalahan dalam draf yang dibuat. Tetapi hal ini dapat diatasi dengan adanya revisi dari dosen pembimbing sebagai ahli materi dan orang yang berkompeten dibidangnya sebagai ahli media.

b) Mengevaluasi dan meninjau kembali

Media Pembelajaran Video Interaktif yang telah dikembangkan ini selanjutnya divalidasi kepada dosen pembimbing ahli materi dan ahli media. Tahap ini meliputi penilaian kualitas dari aspek materi, penyajian dan bahasa. Pada tahap ini didapatkan masukan dan revisi, kemudian siap diuji kualitasnya kepada guru biologi. Hasil dari pengembangan ini adalah media pembelajaran video interaktif identifikasi hewan vertebrata yang dikemas dalam bentuk PPT interaktif yang dapat digunakan secara individual. 
c) Revisi Media Pembelajaran Video Interaktif

Setelah disetujui oleh dosen pembimbing sebagai ahli materi dan ahli media, diperoleh masukan-masukan untuk memperbaiki media video interaktif. Penilaian ditinjau dari aspek materi, aspek penyajian dan aspek bahasa, kemudian dilakukan tindak lanjut untuk menyempurnakan media video interaktif tersebut. Setelah dilakukan perbaikan produk kembali, maka media video interaktif siap diuji kualitasnya kepada guru biologi.

\section{Pembahasan Penilian Validasi Media Pembelajaran Video Interaktif}

Hasil penelitian yang disusun dalam bentuk Media Pembelajaran Video Interaktif. Selanjutnya dilakukan validasi oleh ahli materi, ahli media, dan guru biologi untuk mengetahui apakah media pembelajaran video interaktif yang disusun layak untuk dijadikan media dalam pembelajaran atau tidak.

\section{a. Ahli Materi}

Dra. Tri Wiharti, M.Si sebagai validator ahli materi media pembelajaran video interaktif. Validasi dilakukan dengan memberikan kuesioner kepada validator. Kuesioner berisi instrumen penilaian berupa pertanyaan terstuktur beserta rubrik penilaian, kolom saran dan kolom kesimpulan dari validator.

Perolehan skor penilaian validator sebanyak 40, skor tersebut kemudian dianalisis dengan menggunakan teknis analisis data presentase yaitu skor yang diperoleh dibagi dengan skor maksimal kemudian dikonversi dalam bentuk presentase. Skor maksimal dalam penilaian media pembelajaran video interaktif ini adalah 44. Setelah dikonversi dalam bentuk presentase, skor menjadi 90,9\%. Menurut Suparno dalam Harumi (2014), Presentase tersebut menunjukkan bahwa media pembelajaran video interaktif yang telah disusun masuk kategori tingkat validasi yang pertama yaitu antara $80 \%-100 \%$, skor dan presentase kuesioner tersebut menyatakan bahwa media pembelajaran video interaktif yang telah disusun memiliki kategori yang sangat valid dan siap dimanfaatkan sebagai salah media pembelajaran di SMA. Selain memberikan skor penilaian, validator juga memberikan saran dan kesimpulan terhadap multimedia interaktif.

b. Ahli Media

Winda Arum Wardani, S.Kom sebagai validator ahli media video interaktif. Validasi dilakukan dengan memberikan kuesioner kepada validator. Kuesioner berisi instrumen penilaian berupa pertanyaan terstuktur beserta rubrik penilaian, kolom saran dan kolom kesimpulan dari validator.

Perolehan skor penilaian validator sebanyak 85, skor tersebut kemudian dianalisis dengan menggunakan teknis analisis data presentase yaitu skor yang diperoleh dibagi dengan skor maksimal kemudian dikonversi dalam bentuk presentase. Skor maksimal dalam penilaian media video interaktif ini adalah 96. Setelah dikonversi dalam bentuk presentase, skor menjadi 88,54\%. Menurut Suparno dalam Harumi (2014), Presentase tersebut menunjukkan bahwa media video interaktif yang telah disusun masuk kategori tingkat validasi yang pertama yaitu antara $80 \%$ $100 \%$, skor dan presentase kuesioner tersebut menyatakan bahwa media pembelajaran video interaktif yang telah disusun memiliki kategori yang sangat valid dan siap dimanfaatkan sebagai salah media pembelajaran di SMA

Dengan demikian, produk penelitian ini dapat dimanfaatkan di Sekolah Menengah Atas (SMA) sebagai alternative media 
pembelajaran

biologi

materi

Keanekaragaman Hayati, KD 3.2 tentang "Menganalisis data hasil observasi tentang berbagai tingkat keanekaragaman hayati (gen, jenis, dan ekosistem) di Indonesia".

c. Guru biologi

Juari, S.Pd sebagai validator guru biologi dari SMA Veteran 1 Sukoharjo. Validasi dilakukan dengan memberikan kuesioner kepada validator. Kuesioner berisi instrumen penilaian berupa pertanyaan terstuktur beserta rubrik penilaian, kolom saran dan kolom kesimpulan dari validator.

Perolehan skor penilaian validator sebanyak 74, skor tersebut kemudian dianalisis dengan menggunakan teknis analisis data presentase yaitu skor yang diperoleh dibagi dengan skor maksimal kemudian dikonversi dalam bentuk presentase. Skor maksimal dalam penilaian media video interaktif ini adalah 80. Setelah dikonversi dalam bentuk presentase, skor menjadi 92,5\%. Menurut Suparno dalam Harumi (2014), Presentase tersebut menunjukkan bahwa media video interaktif yang telah disusun masuk kategori tingkat validasi yang pertama yaitu antara 80\%$100 \%$, skor dan presentase kuesioner tersebut menyatakan bahwa multimedia interaktif yang telah disusun memiliki kategori yang sangat valid dan siap dimanfaatkan sebagai salah media pembelajaran di SMA.

Ir. Yuni Susilastuti sebagai validator guru biologi dari SMA N 1 Nguter. Validasi dilakukan dengan memberikan kuesioner kepada validator. Kuesioner berisi instrumen penilaian berupa pertanyaan terstuktur beserta rubrik penilaian, kolom saran dan kolom kesimpulan dari validator.

Perolehan skor penilaian validator sebanyak 78, skor tersebut kemudian dianalisis dengan menggunakan teknis analisis data presentase yaitu skor yang diperoleh dibagi dengan skor maksimal kemudian dikonversi dalam bentuk presentase. Skor maksimal dalam penilaian media video interaktif ini adalah 80 . Setelah dikonversi dalam bentuk presentase, skor menjadi 97,5\%. Menurut Suparno dalam Harumi (2014), Presentase tersebut menunjukkan bahwa media video interaktif yang telah disusun masuk kategori tingkat validasi yang pertama yaitu antara 80\%$100 \%$, skor dan presentase kuesioner tersebut menyatakan bahwa media video interaktif yang telah disusun memiliki kategori yang sangat valid dan siap dimanfaatkan sebagai salah media pembelajaran di SMA.

Berdasarkan validasi produk, saran dan kesimpulan yang dinilai oleh dua validator yaitu guru biologi SMA Veteran 1 Sukoharjo dan SMA N 1 Nguter. Dengan demikian, produk penelitian ini dapat dimanfaatkan di Sekolah Menengah Atas (SMA) sebagai alternatif media pembelajaran biologi materi Keanekaragaman Hayati, KD 3.2 tentang "Menganalisis data hasil observasi tentang berbagai tingkat keanekaragaman hayati (gen, jenis, dan ekosistem) di Indonesia".

\section{Pembahasan Media Video Interaktif sebagai Media Pembelajaran}

Produk hasil penelitian disusun menjadi salah satu media pembelajaran berupa media interaktif keanekaragaman hayati yang dapat dimanfaatkan di SMA/MA. Media pembelajaran video interaktif tersebut bernama "SMART Biodiversity" memiliki arti kata "Smart" dalam bahasa Inggris adalah Pintar, kata "Biodiversity" yang berarti Biodiversitas (Keanekaragaman Hayati) adalah materi yang dibahas dalam media tersebut. Dengan adanya media pembelajaran tersebut, diharapkan siswa dapat lebih memahami materi pembelajaran yang disampaikan. 
Hasil penelitian lain juga mengungkapkan bahwa hasil penelitian aves di gunuung merbabu dapat dijadikan sebagai bahan pembuatan multimedia interaktif biologi SMA (Fadhillah, 2020).

Penggunaan media video interaktif keanekaragaman hayati sebagai salah satu media pembelajaran di sekolah berdasarkan pada landasan pokok yaitu kurikulum yang berlaku di sekolah. Media video interaktif yang telah disusun memiliki kelebihan yaitu berisi teks, gambar, audio-video, dan kuis interaktif. Dalam media video interaktif terdapat daftar spesies identifikasi hewan vertebrata khususnya kelas mamalia, ordo artiodactyla, dan famili cervidae di Taman Satwa Taru Jurug Surakarta yang belum ditemukan pada media yang lain.

\section{KESIMPULAN DAN SARAN}

Berdasarkan data pengamatan dan pembahasan, maka dapat disimpulkan sebagai berikut:

1. Hasil identifikasi di Taman Satwa Taru Jurug Surakarta diperoleh data, bahwa di Taman Satwa Taru Jurug tersebut peneliti menemukan 3 spesies hewan yaitu Cervus unicolor (Rusa Sambar), Cervus timorensis (Rusa Timor), Axis-axis (Rusa Tutul) yang ketiganya masuk kedalam sub filum Vertebrata, kelas Mamalia, ordo Artiodactyla dan famili Cervidae.

2. Produk media pembelajaran video interaktif hasil identifikasi hewan Vertebrata di Taman Satwa Taru Jurug Surakarta untuk siswa SMA/MA kelas X pada pokok bahasan Keanekaragaman Hayati telah berhasil disusun. Karakteristik proses pengembangan multimedia interaktif meliputi tahap Planning (perencanaan), Design (penyusunan draf, sistematika penulisan, dan alat evaluasi), Development (pengembangan, penulisan, penyuntingan, dan revisi media video interaktif).

3. Karakteristik produk pengembangan media pembelajaran video interaktif yang terdiri dari: halaman judul, petunjuk penggunaan, $\mathrm{CV}$ penulis, materi Keanekaragaman Hayati, gambar, video, kuis interaktif dan hasil identifikasi hewan Vertebrata di Taman Satwa Taru Jurug Surakarta dan penutup.

4. Produk penelitian ini merupakan media pembelajaran video interaktif yang sudah dilakukan proses validasi oleh ahli materi, ahli media dan guru biologi. Penilaian oleh ahli materi diperoleh presentase 90,9\% (sangat valid), penilaian ahli media diperoleh presentase $88,5 \%$ (sangat valid), penilaian oleh guru biologi SMA Veteran 1 Sukoharjo diperoleh presentase 92,5\% (sangat valid) dan untuk penilaian oleh guru biologi SMA N 1 Nguter diperoleh presentase $97,5 \%$ (sangat valid) untuk dimanfaatkan di Sekolah Menengah Atas sebagai salah satu media pembelajaran biologi materi Invertebrata, KD 3.2 tentang "Menganalisis data hasil observasi tentang berbagai tingkat keanekaragaman hayati (gen, jenis, dan ekosistem) di Indonesia",

5. Aplikasi/penerapan media pembelajaran video interaktif dapat diterapkan di dalam kelas dengan memanfaatkan media video interaktif sebagai salah satu media pembelajaran sesuai dengan materi atau $\mathrm{KD}$ yang telah tertulis pada silabus.

\section{UCAPAN TERIMAKASIH}

Terimakasih kepada Bapak dan Ibu tercinta yang senantiasa memberi dukungan dan Do'a, sahabat-sahabatku yang senantiasa menyemangatiku, dan tak pernah lelah mengingatkanku untuk segera menyelesaikan skripsi, Bapak dan Ibu Dosen Universitas Veteran Bangun Nusantara Sukoharjo.

\section{DAFTAR PUSTAKA}

Anantyarta, P. (2017). Identifkasi Variasi Genetik Kerbau (Bubalus Bubalis) Pacitan Dan Tuban Berbasis Mikrosatelit. Jurnal Ilmiah IKIP Budi Utomo. IKIP Budi Utomo Malang. 
Fadhillah, D. N. (2020). Identifikasi Aves di Kawasan Taman Nasional Gunung Merbabu Sebagai Bahan Pembuatan Multimedia Interaktif Biologi SMA. Journal of Biology Learning, 2(1).

Masykuri, M.F. (2013). Modul Pengayaan Biologi Peminatan untuk SMA/MA Kelas X. Surakarta: PT. Putra Nugraha Sentosa.

Sibarani,H.L. (2018). Jenis Dan Prevalensi Endoparasit Pada Feses Rusa Sambar (Cervus Unicolor) Dan Rusa Tutul (Axis-Axis) Di Penangkaran Rusa Universitas Sumatera Utara. [SKRIPSI]. Medan. Univesitas Sumatera Utara

Susanto, A. (2013). Teori Belajar dan Pembelajaran di Sekolah Dasar. Jakarta: Prenadamedia Group.

Sudarisman, S. (2015). Memahami hakikat dan karakteristik pembelajaran Biologi dalam upaya menjawab tantangan abad 21 serta Optimalisasi implementasi kurikulum 2013. Jurnal Online. FKIP UNS. Surakarta. 